\title{
Studies of surfactants in photogalvanic cells - NaLS-EDTA and azur-B system
}

\author{
R C MEENA*, GAUTAM SINGH, NIDHI TYAGI and MANJU KUMARI \\ Department of Chemistry, Jai Narain Vyas University, Jodhpur 342 001, India \\ e-mail: rcmeena007@ rediffmail.com
}

MS received 23 September 2003; revised 5 February 2004

\begin{abstract}
Photogalvanic effects were studied in photogalvanic cells containing sodium lauryl sulphate as surfactant, EDTA as reductant and azur-B as photosensitizer. The photopotential and photocurrent generated were $814.0 \mathrm{mV}$ and $255.0 \mu \mathrm{A}$ respectively. The observed conversion efficiency was $1.2 \%$ and the maximum power of cell was $207.57 \mu \mathrm{W}$. The storage capacity of the cell was $26.0 \mathrm{~min}$ in dark. The effect of different parameters on electrical output of the cell was observed. A mechanism has been proposed here for the generation of photocurrent in photogalvanic cells.
\end{abstract}

Keywords. Sodium lauryl sulphate; fill factor; conversion efficiency; power point.

\section{Introduction}

The photogeneration of electricity has attracted the attention of scientists as viable media for solar energy conversion and storage in photogalvanic cells with bright future prospects.

The photogalvanic effect was first of all reported by Rideal and Williams ${ }^{1}$ but it was systematically investigated by Rabinowitch ${ }^{2,3}$. Becquere ${ }^{4,5}$ first observed in 1839 the flow of current between two unsymmetrical illuminated metal electrodes in sunlight. Thereafter, Kaneka and Yamada ${ }^{7}$, Murthy et $a l,{ }^{8}$ Rohtagi Mukherjee et $a l,{ }^{6}$ Ameta et $a l^{9-11}$ and Gangotri et $a l^{12-14}$ have reported some interesting photogalvanic systems. The theoretical conversion efficiency of photogalvanic cells is about $18 \%$ but the observed conversion efficiencies are quite low owing the low stability of azur-B, back electron transfer, aggregation of azur-B molecules around electrodes etc. Hoffman and Lichtin ${ }^{15}$ have discussed various problems encountered in the development of this field.

A detailed literature ${ }^{16-33}$ survey reveals that different photosensitizers and EDTA have been used in photogalvanic cells, but no attention has been paid to use of the NaLS-azur-B system in the photogalvanic cell for solar energy conversion and storage. The present work was undertaken to study this system.

\footnotetext{
*For correspondence
}

\section{Experimental}

NaLS (SD Fine-Chem Limited) and sodium hydroxide (SD Fine) were used in the present work. All the solutions were prepared in doubly distilled water and kept in amber coloured containers to protect them from sunlight. A mixture of solutions of NaLS, azur-B and sodium hydroxide was taken in an $\mathrm{H}$-shaped glass tube. A platinum electrode $(1.0 \times$ $1.0 \mathrm{~cm}^{2}$ ) was immersed into one arm of an H-tube and a saturated calomel electrode (SCE) was kept in the other. The whole system was first placed in dark till a stable potential was obtained, then the arm containing the SCE was kept in the dark, while the platinum electrode was exposed to a $200 \mathrm{~W}$ tungsten lamp. A water-filter was used to cut off infrared radiations. The photochemical bleaching of azur-B was studied potentiometrically. A digital pHmeter (Agronic Model 511) and a micro-ammeter (OSAW, India) were used to measure the potential and current generated by the system respectively.

\section{Results and discussion}

\subsection{Effect of variation of sodium lauryl sulphate concentration}

It is observed that electrical output of the cell increases on increasing the concentration of NaLS (surfactant), reaching a maximum value. On further 
increase in concentration, fall in photopotential, photocurrent and power of the photogalvanic cell is seen, as is summarized in table 1 .

\subsection{Effect of variation of $p H$}

The electrical output of the cell is affected by variation in $\mathrm{pH}$ of the system. It is observed from table 2 that there is an increase in electrical output of the cell with the increase in $\mathrm{pH}$ values. At $\mathrm{pH} 12.78$ a maxima is obtained. On further increase in $\mathrm{pH}$, there is decrease in photopotential and photocurrent. Thus, photogalvanic cells containing the NaLS-EDTAazur-B system are quite sensitive to the $\mathrm{pH}$ of the solutions.

It is observed that the $\mathrm{pH}$ for the optimum condition has a relation with $\mathrm{pKa}$ of the reductant and the desired $\mathrm{pH}$ is higher than its $\mathrm{p} K a$ value $(\mathrm{pH}>\mathrm{p} K a)$.
The reason may be the availability of reductant in its anionic form, which is a better donor form.

\subsection{Effect of variation of EDTA concentration}

The electrical output of the cell is affected by the variation of concentration of reducing agent (EDTA) in the system. These results are summarized in table 3.

Lower concentration of reducing agents results in fall in electrical output because fewer reducing agent molecules are available for electron donation to dye molecules.

Large concentration of reducing agent results in decrease in electrical output, because the large number of reducing agent molecules hinder the dye molecules from reaching the electrode in the desired time limit.

Table 1. Effect of variation of cetyl trimethyl ammonium bromide concentration.

[Azur-B] $=4.96 \times 10^{-5} \mathrm{M} ; \quad[$ EDTA $]=2.24 \times 10^{-3} \mathrm{M} ; \mathrm{pH}=12.78$; light intensity $=10 \cdot 4 \mathrm{~mW} \mathrm{~cm}^{-2}$; temp $=303 \mathrm{~K}$.

\begin{tabular}{lrrrrr}
\hline & \multicolumn{5}{c}{$[\mathrm{NaLS}] \times 10^{-3} \mathrm{M}$} \\
\cline { 2 - 6 } Parameters & $7 \cdot 2$ & 6.8 & $6 \cdot 4$ & $6 \cdot 0$ & $5 \cdot 6$ \\
\hline Photopotential $(\mathrm{mV})$ & $753 \cdot 0$ & 792.0 & $814 \cdot 0$ & $593 \cdot 0$ & $470 \cdot 0$ \\
Photocurrent $(\mu \mathrm{A})$ & $275 \cdot 0$ & $300 \cdot 0$ & $300 \cdot 0$ & $100 \cdot 0$ & $110 \cdot 0$ \\
Power $(\mu \mathrm{W})$ & $188 \cdot 0$ & $205 \cdot 0$ & $207 \cdot 0$ & $129 \cdot 65$ & 137.6 \\
\hline
\end{tabular}

Table 2. Effect of variation of $\mathrm{pH}$.

$\left[\right.$ Azur-B] $=4.96 \times 10^{-5} \mathrm{M} ;[\mathrm{NaLS}]=6.40 \times 10^{-3} \mathrm{M} ;[$ EDTA $]=2.24 \times 10^{-3} \mathrm{M}$; temp. $=303 \mathrm{~K}$; light intensity $=10 \cdot 4 \mathrm{~mW} \mathrm{~cm}^{-2}$

\begin{tabular}{lccccc}
\hline & \multicolumn{5}{c}{$\mathrm{pH}$} \\
\cline { 2 - 6 } Parameters & $12 \cdot 83$ & $12 \cdot 80$ & $12 \cdot 78$ & $12 \cdot 74$ & $12 \cdot 71$ \\
\hline Photopotential $(\mathrm{mV})$ & $593 \cdot 0$ & $784 \cdot 0$ & $838 \cdot 0$ & $337 \cdot 0$ & 301.0 \\
Photocurrent $(\mu \mathrm{A})$ & $100 \cdot 0$ & $275 \cdot 0$ & $275 \cdot 0$ & $100 \cdot 0$ & $85 \cdot 0$ \\
Power $(\mu \mathrm{W})$ & $29 \cdot 65$ & 132.6 & 175.98 & $168 \cdot 5$ & 21.07 \\
\hline
\end{tabular}

Table 3. Effect of variation of EDTA concentration.

$\left[\right.$ Azur-B] $=4.96 \times 10^{-5} \mathrm{M} ;[\mathrm{NaLS}]=6.4 \times 10^{-3} \mathrm{M}$; light intensity $=10.4 \mathrm{~mW} \mathrm{~cm}^{-2}$; $\mathrm{pH}=12.78$; temp. $=303 \mathrm{~K}$

\begin{tabular}{lccccc}
\hline & \multicolumn{5}{c}{$\left[\right.$ EDTA] $\times 10^{-3} \mathrm{M}$} \\
\cline { 2 - 6 } Parameters & 2.32 & 2.28 & $2 \cdot 24$ & $2 \cdot 20$ & $2 \cdot 16$ \\
\hline Photopotential $(\mathrm{mV})$ & $155 \cdot 0$ & $593 \cdot 0$ & $837 \cdot 0$ & $307 \cdot 0$ & $198 \cdot 0$ \\
Photocurrent $(\mu \mathrm{A})$ & $100 \cdot 0$ & $100 \cdot 0$ & $300 \cdot 0$ & $50 \cdot 0$ & $75 \cdot 0$ \\
Power $(\mu \mathrm{W})$ & 11.62 & $29 \cdot 65$ & $217 \cdot 0$ & 82.89 & $99 \cdot 0$ \\
\hline
\end{tabular}




\subsection{Effect of variation of azur-B (dye) concentration}

Dependence of photopotential and photocurrent on the concentration of azur-B (dye) was studied and the results are summarized in table 4.

Lower concentration of dye result into fall in photopotential and photocurrent because fewer dye molecules are available for the excitation and conescutive donation of the electrons to the platinum electrode. The greater concentration of dye also results in decrease in electrical output as the intensity of light reaching the dye molecule near the electrode decreases due to absorption of the major portion of the light by dye molecules present in the path.

\subsection{Effect of diffusion length}

The effect of variation of diffusion length (distance between the two electrodes) on the current parameters of the cell was studied using H-type cells of different dimension. The results are reported in table 5.

It was observed that there is sharp increase in photocurrent $i_{\max }$ in the first few minutes of illumination and then there is a gradual decrease to a stable value of photocurrent. This photocurrent at equili- brium is represented as $\left(i_{\text {eq }}\right)$. This kind of photocurrent behaviour is an initial rapid reaction followed by a slow rate determining step at a later stage.

On the basis of the effect of diffusion path length on the current parameters, as investigated by Kaneko and Yamada ${ }^{7}$ it may be concluded that the leuco or semi reduced form of dye and the dye itself are the main electroactive species at the illuminated and the dark electrodes respectively. However, the reducing agents and its oxidized products behave as the electron carries in the cell diffusing through the path.

\subsection{Current-voltage (i-V) characteristics and conversion efficiency}

It was observed that the $i-V$ curve of the cell deviates from its regular rectangular shape as given in figure 1 .

A point on the $i-V$ curve called the power point (PP) is determined where the product of potential and current is maximum. The value of potential and current at the power point are represented as $V_{P P}$ and $i_{\mathrm{PP}}$ respectively. With the help of the $i-V$ curve the fill factor and the conversion efficiency of cell are determined as 0.45 and $1.20 \%$ respectively, using the following formulae

Table 4. Effect of variation of azur-B (dye) concentration. $[$ EDTA $]=2.24 \times 10^{-3} \mathrm{M} ;[\mathrm{NaLS}]=6.4 \times 10^{-3} \mathrm{M}$; light intensity $=10.4 \mathrm{~mW} \mathrm{~cm}^{-2}$; $\mathrm{pH}=12 \cdot 78$; temp. $=303 \mathrm{~K}$

\begin{tabular}{lrrrrr}
\hline & \multicolumn{5}{c}{$\left[\right.$ Azur-B] $\times 10^{-5} \mathrm{M}$} \\
\cline { 2 - 6 } Parameter & $5 \cdot 12$ & $5 \cdot 04$ & 4.96 & 4.92 & 4.88 \\
\hline Photopotential $(\mathrm{mV})$ & $317 \cdot 0$ & $728 \cdot 0$ & $838 \cdot 0$ & $657 \cdot 0$ & $593 \cdot 0$ \\
Photocurrent $(\mu \mathrm{A})$ & $50 \cdot 0$ & $285 \cdot 0$ & $300 \cdot 0$ & $100 \cdot 0$ & $50 \cdot 0$ \\
Power $(\mu \mathrm{W})$ & $95 \cdot 1$ & $182 \cdot 0$ & $208 \cdot 0$ & 29.65 & $99 \cdot 25$ \\
\hline
\end{tabular}

Table 5. Effect of diffusion length.

$\left[\right.$ Azur-B] $=4.96 \times 10^{-5} \mathrm{M} ;[\mathrm{NaLS}]=6.4 \times 10^{-3} \mathrm{M} ;[$ EDTA $]=2.24 \times 10^{-3} \mathrm{M} ; \mathrm{pH}=12.78 ;$ temp. $=303 \mathrm{~K}$; light intensity $=10.4 \mathrm{~mW} \mathrm{~cm}^{-2}$

\begin{tabular}{|c|c|c|c|}
\hline $\begin{array}{l}\text { Diffusion path length } \\
D_{L}(\mathrm{~mm})\end{array}$ & $\begin{array}{l}\text { Maximum photocurrent } \\
\qquad i_{\max }(\mu \mathrm{A})\end{array}$ & $\begin{array}{l}\text { Equilibrium photocurrent } \\
\qquad i_{\mathrm{eq}}(\mu \mathrm{A})\end{array}$ & $\begin{array}{l}\text { Rate of initial generation } \\
\text { of current }\left(\mu \mathrm{A} \mathrm{min} \min ^{-1}\right)\end{array}$ \\
\hline $35 \cdot 0$ & $275 \cdot 0$ & $250 \cdot 0$ & $54 \cdot 2$ \\
\hline $40 \cdot 0$ & $300 \cdot 0$ & $255 \cdot 0$ & 58.8 \\
\hline $45 \cdot 0$ & $300 \cdot 0$ & $260 \cdot 0$ & $60 \cdot 3$ \\
\hline $50 \cdot 0$ & $100 \cdot 0$ & $270 \cdot 0$ & $56 \cdot 6$ \\
\hline $55 \cdot 0$ & $110 \cdot 0$ & $250 \cdot 0$ & $52 \cdot 2$ \\
\hline
\end{tabular}


Table 6. Conversion efficiency and sunlight conversion data.

$\left[\right.$ Azur-B] $=4.96 \times 10^{-5} \mathrm{M}$; [EDTA] $=2.24 \times 10^{-3} \mathrm{M} ;[\mathrm{NaLS}]=6.40 \times 10^{-3} ; \mathrm{pH}=12.78 ;$ temp. $=$ $303 \mathrm{~K}$; light intensity $=10 \cdot 4 \mathrm{~mW} \mathrm{~cm}^{-2}$

\begin{tabular}{lccc}
\hline & \multirow{2}{*}{$\begin{array}{c}\text { Conversion } \\
\text { efficiency }(\%)\end{array}$} & Photopotential $(\mathrm{mV})$ & Photocurrent $(\mu \mathrm{A})$ \\
\cline { 3 - 4 } Conditions & 0.32 & $755 \cdot 0$ & $110 \cdot 0$ \\
Without micelle & 1.20 & 814.0 & $255 \cdot 0$ \\
\hline In presence of NaLS & &
\end{tabular}

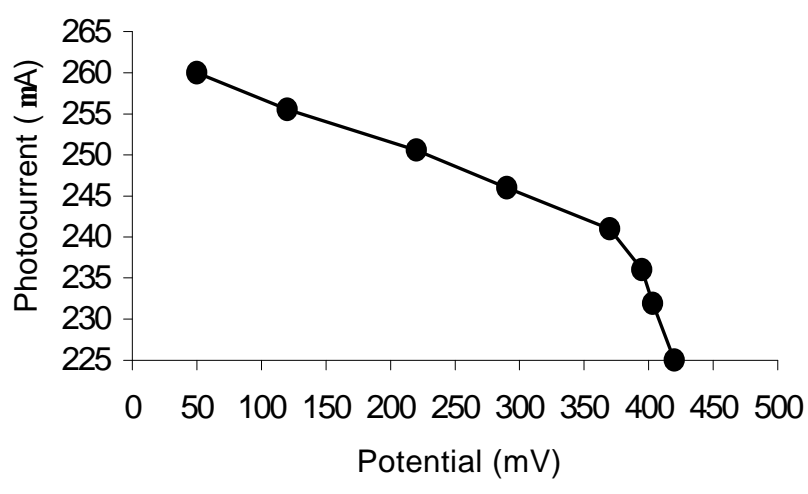

Figure 1. Current-voltage $(i-V)$ curve of the cell.

Table 7. Possible combination for electroactive species

\begin{tabular}{ll}
\hline In illuminated chamber & \multicolumn{1}{c}{ In dark chamber } \\
\hline Azur-B & Oxidized form of reductant $\left(\mathrm{R}^{+}\right)$ \\
Leuco or semi azur-B & Oxidized form of reductant $\left(\mathrm{R}^{+}\right)$ \\
Leuco or semi azur-B & Azur-B \\
\hline
\end{tabular}

fill factor $=\left(V_{P P} \times i_{P P}\right) /\left(V_{o c} \times i_{s c}\right)$,

conversion efficiency

$$
=\left(V_{P P} \times i_{P P}\right) /\left(10.4 \mathrm{mWcm}^{-2}\right) \times 100 \%,
$$

where $V_{p p}, i_{p p}, V_{o c}$ and $i_{s c}$ are the potential at power point, current at power point, open circuit voltage and short circuit current respectively. The system (at its optimum condition) was exposed to sunlight. The conversion data for the photogalvanic cell is reported in table 6.

\subsection{Cell performance}

The performance of the cell was studied by applying the external load necessary to maintain current and potential at the power point after removing the source of light until the output (power) reduces to its half value at the power point in the dark. It was observed that the cell can be used in the dark at its power point for $26.0 \mathrm{~min}$.

\section{Role of micelles}

The utility of surfactants ${ }^{28}$ in photogalvanic cells with respect to their nature has been investigated and found to follow the order - anionic surfactants > neutral surfactants $>$ cationic surfactants. Alkaties et $a l^{29}$ have studied the photoejection of electrons from dye-surfactant systems, suggesting the tunneling of photoelectrons from the micellar phase to the aqueous phase, whereas Mukhopadhaya and Bhowmik ${ }^{30}$ have suggested the probability of some charge transfer between surfactant and dye.

Photogalvanic cells containing azur-B and EDTA (without micelles) show a conversion efficiency of $0.32 \%$, and addition of sodium lauryl sulphate (micelles) increases the conversion efficiency, i.e. 1.20\%. The used NaLS solubilises the dye more easily and stabilizes the system and may increase the probability of charge transfer between surfactant and the dye in the system.

\section{Electroactive species}

Various probable processes may be considered for the photocurrent generation in photogalvanic cells. The results of the effect of diffusion length on current parameters were utilized to learn more about the electroactive species. The possible combinations of electroactive species in photogalvanic cell are tabulated in table 7.

The oxidized form of the reductant is formed only in the illuminated chamber and if it is considered to be the electroactive species in the dark chamber then it must diffuse from the illuminated chamber to the dark chamber to accept an electron from the electrode. 
As a consequence, the maximum photocurrent $\left(i_{\max }\right)$ and rate of increase in photocurrent should decrease with an increase in diffusion length, but this was not observed experimentally. The value $\left(i_{\mathrm{eq}}\right)$ is also observed to be independent with respect to change in diffusion length (rather it decrease slightly). Therefore, it may be concluded that the main electroactive species are the leuco or semi-azur-B and the dye azur- $\mathrm{B}$ in the illuminated and dark chambers respectively. However, the reductant and its oxidized products act only as electron carriers in the path.

\section{Mechanism}

On the basis of the above investigations the mechanism of the photocurrent generation in the photogalvanic cell can be proposed as follows.

\section{Illuminated chamber}

Bulk solution

$$
\begin{aligned}
& \text { Azur-B } \stackrel{h v}{\longrightarrow} \text { Azur-B*, } \\
& \text { Azur-B* }+\mathrm{R} \rightarrow \text { Azur-B }^{-}+\mathrm{R}^{+},
\end{aligned}
$$

At electrode

$$
\text { Azur- } \mathrm{B}^{-} \rightarrow \text { Azur- } \mathrm{B}+e^{-},
$$

\section{Dark chamber}

\section{At electrode}

$$
\text { Azur-B }+e^{-} \rightarrow \text { Azur-B }^{-},
$$

\section{Bulk solution}

$$
\text { Azur- } \mathrm{B}^{-}+\mathrm{R}^{+} \rightarrow \text { Azur-B }+\mathrm{R}
$$

where azur- $\mathrm{B}$, azur- $\mathrm{B}^{-}, \mathrm{R}$ and $\mathrm{R}^{+}$are semi or leuco forms, EDTA and its oxidized form respectively.

\section{Acknowledgements}

The authors are grateful to the authorities of the JNV University, especially of the Chemistry Department, for encouragement. Thanks are also due to Mr Pooran Koli for his critical discussions and to
Mr Shankar Lal Meena for interpretation of observations. The authors thank University Grants Commission, New Delhi for financial assistance.

\section{References}

1. Rideal E K and Williams D C 1925 J. Chem. Soc. 258

2. Rabinowitch E 1940 J. Chem. Phys. 8551

3. Rabinowitch E 1940 J. Chem. Phys. 8560

4. Becquerel K 1839 C. R. Acad. Sci. (Paris) 914

5. Becquerel K 1839 C. R. Acad. Sci. (Paris) 9561

6. Rohtagi Mukherjee K K, Roy M and Bhowmik B B 1983 Solar Energy 31417

7. Kaneko and Yamada A 1977 J. Phys. Chem. 811213

8. Murthy A S N, Dak H C and Reddy K S 1980 Int. J. Energy Res. 4339

9. Ameta S C, Jain P K, Janu A K and Ameta R 1985 Energy J. 58 8

10. Ameta S C, Khamesra S, Lodha S and Ameta R 1989 J. Photochem. Photobiol. 488

11. Ameta S C, Chittora A K, Gangotri K M and Khamesra S 1989 Z. Phys. Chem. (Leipzig) 270607

12. Gangotri K M, Kalla P, Genwa K R, Chhaganlal, Regar O P and Meena R 1994 J. Indian Council Chem. 219

13. Gangotri K M, Regar O P, Chhaganlal, Kalla P, Genwa K R and Meena R 1996 Int. J. Energy Res. 20 581

14. Gangotri K M, Regar O P, Chhaganlal, Kalla P, Genwa K R and Meena R 1997 Arab J. Sci. Eng. 22 115

15. Hoffman M Z and Lichtin N N 1979 Solar energy (eds) R R Hantala, R B King and C Kutal Clifton (N J Publisher) 153

16. Eisenberg M and Silverman H P 1961 Electrochem. Acta 51

17. Murthy A S N and Reddy K S 1978 Int. Solar Energy Conference, New Delhi, p. 47

18. Yamase T 1981 Photochem. Photobiol. 3411

19. Tamilasaran T and Natarajan S 1983 Indian J. Chem. A20 213

20. Murthy A S N and Reddy K S 1983 Solar Energy 30 39

21. Ameta S C, Dubey G C, Dubey T D and Ameta R 1985 Z. Phys. Chem. (Leipzig) 266200

22. Ameta S C, Dubey G C, Dubey T D and Ameta R 1984 Z. Phys. Chem. (Leipzig) 265838

23. Ameta S C, Ameta R, Seth S and Dubey T D 1988 Afinidad 14264

24. Ameta S C, Ameta R, Seth S and Dubey T D 1989 Z. Phys. Chem. (Leipzig) 270923

25. Ameta S C, Ameta R, Gangotri K M and Seth S 1990 Z. Phys. Chem. (Leipzig) 271427

26. Ameta S C, Ameta R C, Bhardwaj R, Sahasi S and Jain P K 1991 Izrestiva USSR 15

27. Ameta S C, Khamesra K, Chittora A K and Gangorti K M 1989 Int. J. Energy Res. 13643 
28. Ameta S C, Khamesra K, Manju Bala and Gangorti K M 1990 Philos. J. Sci. 371

29. Alkaties S A, Gratzel M and Henglein A 1975 Ber. Bunsenges. Phys. Chem. 541

30. Mukhopadhyay M and Bhowmik B B 1992 J. Photochem. Photobiol. 62223
31. Gangotri K M, Meena R C and Meena R 1999 J. Photochem. Photobiol. A123 93-97

32. Gangotri K M, Meena R C and Meena R 2001 J. Photochem. Photobiol. A141 175-177

33. Meena R C, Singh G and Gangotri K M 2003 Afinidad 69501 